Journal of Bangladesh Academy of Sciences, Vol. 35, No. 1, 19-41, 2011

\title{
SEASONAL VARIATION OF HEAVY METAL CONCENTRATIONS IN WATER AND PLANT SAMPLES AROUND TEJGAON INDUSTRIAL AREA OF BANGLADESH
}

\author{
M. N. MONDOL ${ }^{*}$, A. S. CHAMON, B. FAIZ AND S. F. ELAHI \\ Department of Soil, Water and Environment, University of Dhaka, Dhaka-1000, Bangladesh
}

\section{ABSTRACT}

The Tejgaon industrial area is located within the Dhaka City Corporation and is about $5 \mathrm{~km}$ north of the city centre. Heavy metal concentration at different sampling points varied in different seasons and the maximum amount was observed in the dry season (January). Total $\mathrm{Fe}, \mathrm{Pb}, \mathrm{Cd}, \mathrm{Mn}$, $\mathrm{Ni}, \mathrm{Zn}, \mathrm{Cu}$ and $\mathrm{Cr}$ concentrations in water samples during dry season ranged from $0.11-2.78$, 0.733 - 2.171, $0.05-0.1,0.019-0.34,0.02$ - 0.17, $0.01-0.348,0.10-0.846$, and $0.02-0.09 \mathrm{mg} / \mathrm{l}$ respectively. The present study revealed that the pollution level was very much alarming and increasing slowly day by day. According to WHO guidelines, during both wet and dry seasons $100 \%$ water samples were found in the group of "in excess of tolerable level" for $\mathrm{Pb}(0.01 \mathrm{mg} / \mathrm{l})$. $63,42,79,58$ and $95 \%$ water samples were found in the group of 'in excess of tolerable level' during dry season for $\mathrm{Cu}, \mathrm{Ni}, \mathrm{Cd}, \mathrm{Cr}$ and $\mathrm{Mn}$. Only $26 \%$ of the plant samples had $\mathrm{Ni}(<20 \mathrm{mg} / \mathrm{kg})$ in the normal range and $74 \%(\geq 20-30 \mathrm{mg} / \mathrm{kg})$ plant samples were found in the group of "in excess of tolerable level" during dry season which was $63 \%(\geq 20-30 \mathrm{mg} / \mathrm{kg}$ ) during wet season. Cadmium and $\mathrm{Pb}$ in plant samples found in the group of "in excess of tolerable level" was $26,79 \%$ (> $10 \mathrm{mg} \mathrm{kg}$ ), and 33, 59\% (> $20 \mathrm{mg} / \mathrm{kg}$ ) during wet and dry season, respectively. Plant samples accumulated more and tolerated higher amounts of $\mathrm{Cr}$ during dry season. Average concentration of $\mathrm{Fe}, \mathrm{Mn}$ and $\mathrm{Zn}$ at different locations and plant species were $220.81,279.33$ and $239.81 \mathrm{mg} / \mathrm{kg}$ and 212.0, 313.43 and $159.19 \mathrm{mg} / \mathrm{kg}$ during wet and dry seasons, respectively. Kalmi, water hyacinth, grass (in wet season) and Boro rice, Cabbage (in dry season) accumulated the maximum concentration of $\mathrm{Fe}$ and $\mathrm{Mn}$. In the rainy season the pollution was lower because of heavy rainfall and flushed out through the canal into the adjoining vast flood zone.

Key words: Tejgaon area, Water, Plant, Seasonal variation, Industrial area, Heavy metals

\section{INTRODUCTION}

Heavy metal contamination in water/plant is an increasing world-wide environmental concern (Ahmed et al. 2005). Water and plant have been used much as a recipient of toxic and solid waste from domestic, industrial and agricultural run off. Water-borne chemical pollution entering rivers and streams cause tremendous amounts of destruction. Water pollution by heavy metals due to human activities is causing serious ecological problems in many regions of the world. Metals which are discharged into natural waters at increased concentrations in sewage, industrial effluents or from mining operations can have severe toxicological effects on humans and aquatic ecosystems.

*Corresponding author: <nadiruzzaman_mondol@ hotmail.com>. 
In densely populated and industrialized countries, disposal of waste materials containing heavy metals presents an ever increasing problem. Injudicious applications to soil give rise to accumulation of heavy metals in the top soil, adversely affecting plant and crop quality. One of the major concerns is heavy metal enrichment in edible parts of metal-tolerant crops, creating a hazard to animal and human health.

There are many chemical industries in and around Tejgaon area, namely tannery, paper and pulps, textiles, carbides, pharmaceuticals, pesticides, distilleries etc. which discharge heavy metals like cadmium, lead, chromium, mercury, zinc, arsenic and in a few cases copper and manganese with their effluents and wastes. At present the underground water is not safe for drinking purpose because of heavy metal contamination. The need for the present project emerged from the results of the previous works (Chamon et al. 2005, Alam 2006). These investigations showed that industrial effluents and wastes lead to significant pollution of soils, water and plants around Dhaka city. Heavy metals like $\mathrm{As}, \mathrm{Cr}, \mathrm{Cd}, \mathrm{Pb}, \mathrm{Hg}, \mathrm{Cu}, \mathrm{Zn}$, and nickel (Ni) are toxic for plants and humans. These metals, even in trace amounts, interfere with or inactivate enzymes of living cells (Rahman 1992), therefore their discharge into the environment must be minimized and carefully controlled.

Cadmium and $\mathrm{Pb}$, which have no known beneficial effects, may become toxic to plants and animals if their concentrations exceed certain values (Adriano 1996). Nickel, $\mathrm{Cu}$, and $\mathrm{Zn}$ are three micronutrients essential for plant nutrition. Nickel is an essential component of the enzyme urease, but when Ni concentrations in vegetative tissues of plants exceed $50 \mathrm{mg} / \mathrm{kg}$ dry weight (DW), plants may suffer from excess Ni and exhibit toxicity symptoms (Adriano 1996). Once absorbed, $\mathrm{Cu}$ apparently accumulates in roots, even in cases where roots have been damaged by toxicity (Adriano 1996). Zinc phytotoxicity is reported relatively often, especially for acid and heavily sludged soils (Kabata-Pendias et al. 1993). The physiology and biochemistry of the toxic effects of Zn in plants are likely to be similar to those reported for other heavy metals; however, $\mathrm{Zn}$ is not considered to be highly phytotoxic (Kabata-Pendias et al. 1993).

Dicotyledonous crop plants tend to absorb more metals than monocotyledonous crops (Kabata-Pendias et al. 1993). Monocots, which include most of the cereal crops, are known excluders of metal cations (Baker 1991). Metals are known to be poorly transported to grain tissues (Baker 1991, Sauerbeck 1982). Thus cereal crops such as wheat, barley, oat, rye and corn may be considered as excluders (Sauerbeck 1982).

The plant uptake of chemical species in soil solution is also dependent on a number of plant factors. The characteristics and behaviour of an individual plant species or variety are important in determining the amounts of heavy metals that are taken up from soils. There are a few reports of differing rates of absorption of $\mathrm{Zn}^{2+}$ and $\mathrm{Mn}^{2+}$ between species and 
varieties (Loneragan 1975). The proportions retained vary with the metal and plant species (Chamon et al. 2005). The differing responses of species and varieties to environmental changes will also contribute to differences in uptake of heavy metals from soils.

Available data on the impact of industrial pollution in Bangladesh especially on soils and crops and the mobility in the human food chain are quite limited. Therefore, the agrobased Bangladesh needs careful investigations. The aims of this work are: (1) monitoring seasonal variations of trace elements in the plant and water bodies around Tejgaon area following Balu river, (2) finding the environmental impact of industrial effluents on plant and water bodies, (3) providing the base line data on surface water quality to policy makers to manage and protect water bodies from water pollution for maintaining environmental ecological balance.

\section{MATERIAL AND METHODS}

The main focus of the study is Tejgaon industrial area which is located within the Dhaka City Corporation and about $5 \mathrm{~km}$ north of the city centre. The study area consisted of two distinct areas (Fig. 1). One was the lagoon bordering Tejaon industrial area. This area received the drainage residue of the industrial area, Gulshan model town, Niketan Housing Society, Begunbari and other adjoining residential and slum areas including numerous classified/ unclassified industries. The other consisted of the canal which received the inflow from the lagoon and drained into Balu river.

The effluents from many diverse industries in Tejgaon industrial area flow into a lagoon where the residue settles into a thick muck. It overflows through a sluice gate at Rampura into a channel which flows east for about $10 \mathrm{~km}$ to Balu river which in turn flows into Sitalakhya river (Fig. 1). The whole area is really a flood drainage zone. The common agricultural crop is rice with substantial amount of various vegetables like chilli, capsicum, carrot, cauliflower, cabbage, coriander, water gourd, and tomato. There are abundance of water hyacinth and natural grasses inside the embankment, which are used as fodder for domestic animals.

Water and plant samples were collected from the study area at two dates, September, 2006 (wet season) and January, 2007 (dry season). The sampling sites were georeferenced with GPS (Geographical Positioning System) and marked on the map (Fig. 1) and are given in Table 1. During wet season, due to influx of rain and flood water from surrounding areas, water samples were collected from 29 and plant from 27 sampling points but as water receded in the dry season, both (water and plant) samples were collected from 19 sampling points.

Water samples $(500 \mathrm{ml})$ were collected from each site in deionized polyethylene bottles fitted with liquid-tight stopper from source water. The water samples were immediately acidified with $4 \mathrm{ml}$ of concentrated hydrochloric acid per liter and analyzed within 7 days of collection. 
Plant samples were collected fresh from the field in required amounts, wrapped in polyethylene bags and transported to laboratory and preserved at $+4^{\circ} \mathrm{C}$ for processing on the next day. All plant samples were air dried and placed in oven for drying at $70^{\circ} \mathrm{C}$ and then ground to powder to pass through a $2 \mathrm{~mm}$ sieve for chemical analysis.

One gm of finely ground plant sample was weighed into a $100 \mathrm{ml} \mathrm{Kjeldahl} \mathrm{flask} \mathrm{and}$ digested with $10 \mathrm{ml}$ conc. $\mathrm{HNO}_{3}$ and $2 \mathrm{ml}$ conc. $\mathrm{HClO}_{4}$.

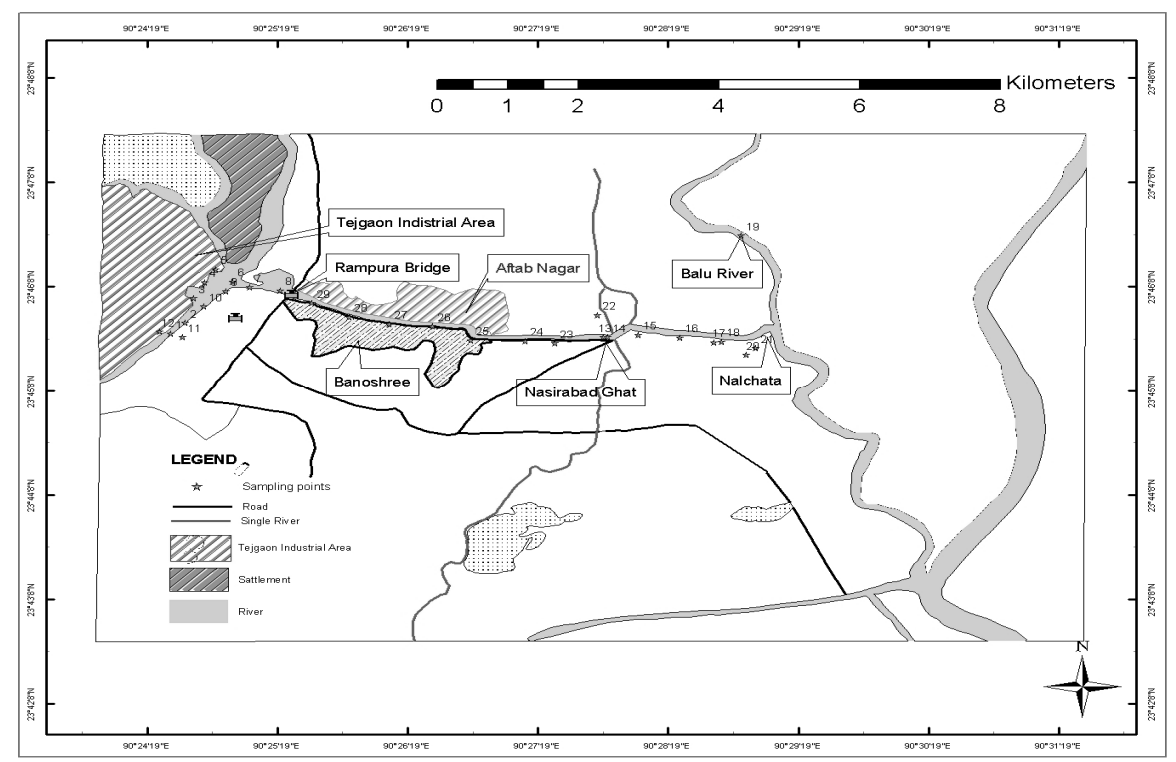

Fig. 1. Location of sampling sites during dry and wet season.

$p H$ : The $\mathrm{pH}$ of water was measured using a glass electrode $\mathrm{pH}$ meter.

$E C$. : Electrical conductivity of water was measured using an EC meter.

TDS: Total dissolved solids of water were measured using a portable TDS meter.

TSS: Total soluble salts in water measured gravimetrically by evaporating $20 \mathrm{ml}$ of water sample at $110^{\circ} \mathrm{C}$ and expressing it in $\mathrm{mg} / \mathrm{kg}$.

$D O, B O D_{5}$, and $C O D$ : Dissolved oxygen, Biological oxygen demand and Chemical oxygen demand in water was measured by Winkler method (Hach 1997).

Free $\mathrm{CO}_{2}$ : Free carbon dioxide in water was determined by titrimetric method (Hach 1997).

$\mathrm{NH}_{4}{ }^{+}$and $\mathrm{NO}_{3}{ }^{-} \mathrm{N}$ : Ammonium- and nitrate-nitrogen in water was measured by microkjeldahl distillation method (Sparks et al. 2001).

The digested water and plant samples were analyzed for heavy metals, e.g., $\mathrm{Cd}, \mathrm{Cr}$, $\mathrm{Cu}, \mathrm{Mn}, \mathrm{Ni}, \mathrm{Pb}$, and $\mathrm{Zn}$ by atomic absorption spectrophotometer (AAS) at the Centre for Advanced Research in Physical, Chemical, Biological and Pharmaceutical Sciences, Dhaka University. 
The results of experiments reported were statistically evaluated by the DMRT. Different letters were used to signify the statistically different results at the $5 \%$ level of significance.

\section{RESULTS AND DISCUSSION}

Table 2 summarizes the maximum, minimum and arithmetic mean of the 10 measured variables in the water samples around Tejgaon industrial area for wet and dry seasons. The physical water quality parameters like pH, EC, TDS, TSS, DO, BOD, $\mathrm{COD}$, free $\mathrm{CO}_{2}$ etc. at different locations for wet and dry season from this research work are already reported and comparison of these quality parameters were made with the parametrical DMRT (Sparks et al. 2001). From the wet and dry season sampling water data (Table 3) following inferences could be made. TSS and TDS values were much above the maximum standards of water quality (Elahi et al. 2008, CPCB 1995). BOD and COD values were much higher and DO values were much lower than the minimum standards of water quality (Elahi et al. 2008, CPCB 1995). The general water quality of the whole study area was extremely poor. Foul smell was so intense that some of the workers had to abandon the sampling protocol. Heavy metal ( $\mathrm{Fe}, \mathrm{Cd}, \mathrm{Cr}, \mathrm{Mn}, \mathrm{Cu}, \mathrm{Zn}, \mathrm{Ni}$ and $\mathrm{Pb}$ ) concentrations varied in water and plant samples in wet and dry season (Fig. 2 AH) (Fig. 3 A-E). Here the heavy metal concentrations at different locations around Tejgaon industrial area are presented and discussed.

During wet season $\mathrm{Zn}$ concentration in water samples at different locations at Tejgaon area ranged from $<0.02-0.08$ and $0-0.348 \mathrm{mg} / \mathrm{l}$ during wet and dry seasons (Fig. 2A). The USPH and WHO standards of Zn for drinking water is $5000 \mu \mathrm{g} / \mathrm{l}$. Our observed values were within these limits. The toxic concentration level of $\mathrm{Zn}$ for general crops is $150-200 \mathrm{ppm}$ (Sauerbeck 1982). Except the plant samples collected from the location Nos. 8, 10, 11 and 17, all other plant samples showed $\mathrm{Zn}$ concentration at toxic concentration level during wet season. Tomato, cabbage, coriander, carrot and grass samples showed $\mathrm{Zn}$ concentration at toxic concentration level during dry season (Fig. $3 \mathrm{~A}$ and B).

The concentration of iron in water samples was found remarkably higher in some locations at the study area. The maximum and minimum concentrations of Fe were 2.78 and $0.11 \mathrm{mg} / \mathrm{l}$ during dry season and 0.17 and $0.01 \mathrm{mg} / \mathrm{l}$ during wet season, respectively (Fig. 2 B). Concentration of Fe in most of the locations exceeded the permissible level of iron in water samples which is set at $0.30 \mathrm{mg} / \mathrm{l}$ during dry season (CPCB 1995). Iron concentration in plant samples at different locations during wet and dry season ranged from 40.21 - 431 and 112 - $286 \mathrm{mg} / \mathrm{kg}$, respectively. The sufficiency range of Fe in crops is normally between 50 - 250 ppm (Tisdale and Nelson 1985). Grass, Bean leaf, water hyacinth at different locations showed values higher than the sufficiency levels during wet season. On the other hand kalmi, tomato, boro rice and grass samples showed higher concentration of $\mathrm{Fe}$ during dry season (Fig. $3 \mathrm{~A}$ and B). 
Journal of Bangladesh Academy of Sciences, Vol. 35, No. 1, 19-41, 2011

Table 1. Description and location of sample collection during wet season (September, 2006) and dry season (January, 2007)

\begin{tabular}{|c|c|c|c|c|c|c|c|c|c|c|c|}
\hline \multicolumn{6}{|c|}{ Wet season (September, 2006) } & \multicolumn{6}{|c|}{ Dry season (January, 2007) } \\
\hline $\begin{array}{l}\text { Location } \\
\text { No. }\end{array}$ & $\begin{array}{l}\text { Location } \\
\text { name }\end{array}$ & $\begin{array}{l}\text { Longitude, } \\
\text { north }\end{array}$ & $\begin{array}{l}\text { Latitude, } \\
\text { east }\end{array}$ & & $\begin{array}{l}\text { Sample } \\
\text { type }\end{array}$ & $\begin{array}{c}\text { Location } \\
\text { No. }\end{array}$ & $\begin{array}{l}\text { Location } \\
\text { name }\end{array}$ & $\begin{array}{l}\text { Longitude } \\
\text { north }\end{array}$ & $\begin{array}{l}\text { Latitude, } \\
\text { east }\end{array}$ & & $\begin{array}{l}\text { ples } \\
\text { pe }\end{array}$ \\
\hline 1 & $\begin{array}{l}\text { Begun bari. Lal } \\
\text { Tanki }\end{array}$ & $23^{0} 45.7$ & $90^{0} 24.5$ & Water & Water & 1 & Rampura bridge & $23^{0} 46.2$ & $90^{0} 25.0$ & Water & Grass \\
\hline 2 & Boubazar & $23^{0} 45.8$ & $90^{0} 24.6$ & $"$ & Bean leaf 1 & 2 & Ullan & $23^{0} 46.2$ & $90^{0} 24.9$ & $”$ & Grass \\
\hline 3 & G S G & $23^{0} 46.0$ & $90^{0} 24.7$ & $"$ & Grass 1 & 3 & Niketon R. area & $23^{0} 46.2$ & $90^{0} 24.8$ & $"$ & Grass \\
\hline 4 & $\begin{array}{l}\text { Back side of } \\
\text { Arong }\end{array}$ & $23^{0} 46.2$ & $90^{0} 24.8$ & $"$ & Grass 2 & 4 & Arong & $23^{0} 46.0$ & $90^{0} 24.7$ & $"$ & Grass \\
\hline 6 & Flood plain & $23^{0} 46.2$ & $90^{0} 25.0$ & $”$ & Grass 4 & 6 & Begun Bari & $23^{0} 45.7$ & $90^{0} 24.6$ & $"$ & Coriander \\
\hline 7 & Ullan & $23^{0} 46.1$ & $90^{0} 24.9$ & 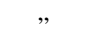 & Bean leaf 2 & 7 & Rampura bridge & $23^{0} 45.7$ & $90^{0} 26.7$ & 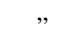 & Cabbage \\
\hline 8 & Rampura bridge & $23^{0} 46.1$ & $90^{0} 25.4$ & $"$ & Water hyacinth 1 & 8 & Banashree ghat & $23^{0} 45.6$ & $90^{0} 27.5$ & $"$ & Boro rice \\
\hline 9 & $\begin{array}{l}\text { Mahanagar } \\
\text { Project }\end{array}$ & $23^{0} 45.9$ & $90^{0} 24.8$ & $"$ & Kalmi 1 & 9 & Meradia & $23^{0} 45.7$ & $90^{0} 28.8$ & $"$ & Tomato \\
\hline 10 & Madhubag & $23^{0} 45.6$ & $90^{0} 24.6$ & $"$ & Water hyacinth 2 & 10 & Balu river & $23^{0} 45.8$ & $90^{0} 29.0$ & $"$ & Boro rice \\
\hline 13. & Nasirabad ghat 2 & $23^{0} 45.7$ & $90^{0} 27.8$ & $"$ & Bean leaf 3 & 13 & Guronagar & $23^{0} 45.6$ & $90^{0} 28.8$ & $"$ & Tomato \\
\hline 14 & Nasirabad 3 & $23^{0} 45.7$ & $90^{0} 27.9$ & $"$ & Kalmi 2 & 14 & Guronagar & $23^{0} 45.6$ & $90^{0} 28.8$ & $"$ & Kalmi \\
\hline 15 & Nasirabad 4 & $23^{0} 45.7$ & $90^{0} 28.1$ & $"$ & - & 15 & Guronagar & $23^{0} 45.6$ & $90^{0} 28.8$ & $"$ & Kalmi \\
\hline 16 & $\begin{array}{l}\text { Guronagar } \\
\text { bottala } 1\end{array}$ & $23^{0} 45.7$ & $90^{0} 28.4$ & $"$ & Kalmi 3 & 16 & Nasirabad & $23^{0} 45.7$ & $90^{0} 28.5$ & $"$ & Kalmi \\
\hline 17 & Guronagar 2 & $23^{0} 45.6$ & $90^{0} 28.7$ & $"$ & - & 17 & Nasirabad & $23^{0} 45.7$ & $90^{0} 27.9$ & $"$ & Tomato \\
\hline 18 & Balu river & $23^{0} 45.6$ & $90^{0} 28.7$ & $”$ & Water hyacinth 4 & 18 & Nasirabad & $23^{0} 45.6$ & $90^{0} 27.9$ & $"$ & Bean leaf \\
\hline 19 & Nalchata ghat 1 & $23^{0} 46.6$ & $90^{0} 28.9$ & $"$ & Kalmi 4 & 19 & Nasirabad ghat & $23^{0} 45.7$ & $90^{0} 27.8$ & water & Kalmi \\
\hline
\end{tabular}


SEASONAL VARIATION OF HEAVY METAL CONCENTRATIONS

(Contd.)

\begin{tabular}{|c|c|c|c|c|c|}
\hline 20 & Nalchata 2 & $23^{0} 45.5$ & $90^{0} 28.9$ & Water & Kalmi 5 \\
\hline 21 & Balu river & $23^{0} 45.55$ & $90^{0} 29.0$ & $"$ & Kalmi 6 \\
\hline 22 & Dasher Kandi & $23^{0} 45.9$ & $90^{0} 27.8$ & $"$ & Water hyacinth 5 \\
\hline 23 & Trimohini 1 & $23^{0} 45.6$ & $90^{0} 27.5$ & ” & Water hyacinth 6 \\
\hline 24 & Trimohini 2 & $23^{0} 45.6$ & $90^{0} 27.2$ & $"$ & Water hyacinth 7 \\
\hline 25 & $\begin{array}{l}\text { Aongargora } \\
\text { Meradia }\end{array}$ & $23^{0} 46.6$ & $90^{0} 26.8$ & $"$ & Water hyacinth 8 \\
\hline 26 & Meradia & $23^{0} 45.7$ & $90^{0} 26.5$ & " & Kalmi 7 \\
\hline 27 & Aftab nagar & $23^{0} 45.8$ & $90^{0} 26.2$ & ” & Water hyacinth 9 \\
\hline 28 & Banashere & $23^{0} 45.8$ & $90^{0} 25.9$ & $"$ & Water hyacinth 10 \\
\hline 29 & Rampura bridge & $23^{0} 46.0$ & $90^{0} 25.6$ & $"$ & Water hyacinth 11 \\
\hline
\end{tabular}


It is seen in the Fig. 2 that the higher concentration of Mn in water was found in the dry season at all locations except at location no 6 and the maximum value was $0.328 \mathrm{mg} / \mathrm{l}$ at the source point. The minimum level of $\mathrm{Mn}$ in water was found during wet season at the locations from 1 to 16 but at all the other locations Mn concentration was found higher which exceeded the maximum permissible USPH/WHO standard of Mn for drinking water purposes $(0.05 \mathrm{mg} / \mathrm{l}$, Fig. $2 \mathrm{C})$. High concentration of $\mathrm{Mn}$ in the water samples might be due to discharge from the small electroplating industries in the catchments of the canal.

Table 2. The minimum, maximum and arithmetic mean concentration of water quality parameters for wet and dry season at Tejgaon area.

\begin{tabular}{lllllll}
\hline \multirow{2}{*}{ Parameters } & \multicolumn{3}{c}{ Wet season } & \multicolumn{3}{c}{ Dry season } \\
\cline { 2 - 7 } & Min. & Max. & Mean & Min. & Max. & Mean \\
\hline $\mathrm{pH}$ & 6.0 & 7.9 & 7.1 & 6.8 & 7.5 & 7.1 \\
$\mathrm{EC} \mu \mathrm{S} / \mathrm{cm}$ & 463.0 & 2060.0 & 852.7 & 584 & 1721 & 835.9 \\
$\mathrm{TDS}(\mathrm{ppm})$ & 80 & 980 & 303.1 & 360 & 980 & 483.3 \\
$\mathrm{TSS} "$ & 400 & 2800 & 1379 & 10 & 250 & 68.9 \\
$\mathrm{DO} \quad$, & 0.0 & 0.1 & 0.1 & 0.1 & 0.3 & 0.2 \\
$\mathrm{BOD} "$ & 1 & 46 & 17 & 0.05 & 0.7 & 0.5 \\
$\mathrm{COD} "$ & 10.8 & 939.6 & 130.5 & 10.6 & 172.5 & 104 \\
$\mathrm{Free} \mathrm{CO} \mathrm{CO}_{2}$, & 8.8 & 132 & 40.5 & 11.4 & 127.6 & 60.6 \\
$\mathrm{NH}_{4}-\mathrm{N}$ & 1.26 & 11.3 & 4.3 & 7.0 & 50.4 & 37.8 \\
$\mathrm{NO}_{3}-\mathrm{N}$ & 0.01 & 33.4 & 6.7 & 19.6 & 1022 & 198.3 \\
\hline
\end{tabular}

Normal concentrations of $\mathrm{Mn}$ in plants are typically from 20 to $500 \mathrm{ppm}$ (Tisdale and Nelson 1985). Plants are injured by excessive amounts of Mn. The average concentration of Mn during wet and dry season were 279.33 and $313.43 \mathrm{mg} / \mathrm{kg}$ which were in the normal range (Fig. $3 \mathrm{~A}$ and B). Water hyacinth at location $8(564 \mathrm{mg} / \mathrm{kg})$ and Kalmi $(439.6 \mathrm{mg} / \mathrm{kg})$ showed the highest concentration of Mn during wet and dry season, respectively.

The concentration of $\mathrm{Pb}$ in water sample ranges from 0.04 to 1.469 and 0.73 to 2.17 $\mathrm{mg} / \mathrm{l}$ during wet and dry season, respectively. The lowest concentration was found only at location 20 (end/meeting point of the canal with Balu river which is too far from the source point) (Fig. 1) during wet season but the level of $\mathrm{Pb}$ was much higher than the permissible levels of WHO and USPH standard at all other locations during both wet and dry season. The highest concentration was at the source point and decreasing with distance (Figs. 1, 2 D).

Plant samples accumulated more and tolerated higher amounts of heavy metals was reported before (Chamon et al. 2005). Average total concentration of $\mathrm{Pb}$ in plant samples were 19.65 and $19.83 \mathrm{mg} / \mathrm{kg}$, respectively, during wet and dry season, at Tejgaon industrial area which were in the range of plants general toxic concentration level 
(Sauerbeck 1982). During 2nd sampling Pb concentration in plant samples were higher than 1st sampling data (Fig. $3 \mathrm{C}$ ). Pb concentration was above the toxic concentration limit in grass and waterhyacinth in some sampling point's e.g. in the point 7, 8, 9, 16, 17, 18, 25, 26 and 27 but low in other plant samples during wet season. During the 2nd sampling $\mathrm{Pb}$ concentrations in all plant samples, except a few, were above the toxic concentration limit (Fig. 3 C).

Cadmium concentrations in the dry season water samples were above the DOE (1992)/WHO (2004) drinking water standards (Fig. 2 E). The mean value was $0.068 \mathrm{mg} / \mathrm{l}$ with the range from 0.05 to $0.10 \mathrm{mg} / \mathrm{l}$ during dry season in water samples.

Average concentrations of $\mathrm{Cd}$ in plant samples were 6.18 and $14.91 \mathrm{mg} / \mathrm{kg}$ during wet and dry season respectively, at Tejgaon industrial area (Fig. $3 \mathrm{D}$ and E). Cd concentration at many sampling points (e.g. point, 13, 22 - 27, 30 - 42, 45 and 46) were above the plants general toxic concentration level (> $10 \mathrm{mg} / \mathrm{kg}$ ) (Sauerbeck 1982). During 2nd sampling Cd concentration in plant samples were higher than 1 st sampling data (Fig. $3 \mathrm{D}$ and $\mathrm{E})$. Cd content was above the toxic concentration level in waterhyacinth and kalmi during wet season at some locations but other plant samples showed elevated concentration of $\mathrm{Cd}$ (Fig. 3 D). During the 2nd sampling Cd concentrations in all plant samples, except a few, were above critical limit (Fig. 3 E).

Cd concentrations in the Gulshan-Baridhara lake water ranged from $0.068-0.091$ and $0.016-0.019 \mathrm{mg} / \mathrm{l}$ during summer and monsoon, respectively, as reported by Mohuya et al. (2010). Tejgaon industrial area soil also contained elevated level of $\mathrm{Cd}$ $(2.6 \mathrm{mg} / \mathrm{kg}$ ) as reported by Chamon et al. (2005). In case of water samples, cadmium concentration in the wet season were found in the normal group in all water samples but in the dry season $79 \%$ water samples ( $>0.05 \mathrm{mg} / \mathrm{l})$ were found in the group of "in excess of tolerable level" (Table 4).

Heavy metal concentration in plant samples was high at the study area. Water hyacinth, kalmi and some grass accumulated significantly higher concentration of $\mathrm{Ni}$ at the sampling point from 16 - 27 during wet season ( $1^{\text {st }}$ sampling). Average concentration of Ni during wet and dry season samples were 21.64 and $26.31 \mathrm{mg} / \mathrm{kg}$, respectively at Tejgaon industrial area which were above the plants general toxic concentration level (Sauerbeck 1982). Metal contaminations of soils, sediments, water bodies and plants have also been reported earlier (Chamon et al. 2005). Concentration of of $\mathrm{Ni}$ at locations 6 to 10 and 16 to 27 (except 22 No. point) were found to be above the toxic level during wet season plant samples. During dry season samples (2nd sampling) Ni concentration in plant samples were higher than 1st sampling data (Fig. $3 \mathrm{C}$ ). Mean concentration of Ni in dry season plant samples was $26.31 \mathrm{mg} / \mathrm{kg}$. The concentration of this metal in rabi plants was above the toxic concentration levels (Sauerbeck 1982). 
Concentrations of $\mathrm{Ni}$ at different locations of the study area during wet season were below the maximum permissible limit value of water except location no $21(<0.1 \mathrm{mg} / \mathrm{l})$. In the dry season at location Nos. 2, 3, 7, 10, 12, 14, and $16 \mathrm{Ni}$ concentrations exceeded the standard values for drinking water (DOE 1992) (> $0.1 \mathrm{mg} / \mathrm{l})$. The highest $\mathrm{Ni}$ concentration was observed at location No. $2(0.17 \mathrm{mg} / \mathrm{l})$ and the lowest at location no 19 $(0.02 \mathrm{mg} / \mathrm{l})$ during dry season for water samples.

Ni content was above the critical limit in cabbage, kalmi, boro-rice, tomato but low in bean leaf and some grass samples during dry season (Fig. 3 D). Ni content was low in grass samples but above critical limit in other samples. During dry season (2nd sampling) $\mathrm{Ni}$ concentrations in all plant samples, except a few, were above toxic concentration limit (Fig. 3 $\mathrm{C}$ and D). Tejgaon area soil contained high Ni concentration i.e. 93.12 and $223.89 \mathrm{mg} \mathrm{Ni} / \mathrm{kg}$ during wet and dry season, respectively, as reported also by Chamon et al. (2005).

Chromium concentrations in the water samples at Tejgaon industrial area varied considerably and ranged from $0.002-0.092$ and $0.02-0.1 \mathrm{mg} / \mathrm{l}$ in the wet and dry season, respectively. Concentration of $\mathrm{Cr}$ in the river Karnaphuli was $0.060 \mathrm{mg} / \mathrm{l}$ and in the river Halda it was $0.01 \mathrm{mg} / \mathrm{l}$ as reported by Bashar et al. (2007). Mohuya et al. (2010) found the concentration of $\mathrm{Cr}$ ranged from $0.048-0.225 \mathrm{mg} / \mathrm{l}$ in the lake of GulshanBaridhara during summer and $0.005-0.035 \mathrm{mg} / \mathrm{l}$ in the monsoon. During wet season, the maximum concentration of $\mathrm{Cr}$ in water sample at Tejgaon area was found at location Nos $9(0.09 \mathrm{mg} / \mathrm{l})$ and the lowest value were at location Nos. 15, 16 and $17(0.002 \mathrm{mg} / \mathrm{l})$ (Fig. 2 F). In the dry season, at location Nos. 1, 4 and 11-19 Cr concentration exceeded all standards for water (CPCB 1995, DOE 1992, WHO 2004) (Fig. 2 F) at Tejgaon area.

Average concentration of $\mathrm{Cr}$ in plant samples were 2.07 and $2.17 \mathrm{mg} / \mathrm{kg}$ during wet and dry season, respectively at Tejgaon industrial area which were above the plants general toxic concentration level (Sauerbeck 1982). Kalmi and waterhyacinth accumulated the highest concentration during wet season but rabi crops e.g. bean leaf, tomato, boro rice, cabbage, coriander, carrot and grass samples showed $\mathrm{Cr}$ concentration above the plants general toxic concentration level (Sauerbeck 1982) during dry season (Fig. 4 A and B). Only capsicum, tomato and kalmi at some locations showed lower values (Fig. 4 B) during dry season.

In the month of January (dry season) the maximum concentration of copper in water sample was found $0.532 \mathrm{mg} / \mathrm{l}$ (mean value) which was $0.349 \mathrm{mg} / \mathrm{l}$ during September (wet season) (Fig. $2 \mathrm{G}$ ). The maximum permissible concentration of copper for aquatic life and fish is $500 \mu \mathrm{g} / \mathrm{l}$. The recommended maximum concentration of $\mathrm{Cu}$ for drinking water supply with respect to USPH and WHO standard is 1000 and $1500 \mu \mathrm{g} / \mathrm{l}$, respectively. The observed values were below the permissible level for drinking purposes. In case of water samples, $100 \%(0-1.0 \mathrm{mgCu} / \mathrm{l})$ water samples were found in the group of normal level 
during both seasons (Fig. 2 G) for drinking water purposes. Chowdhry et al. (2007) reported the concentrations of $\mathrm{Cu}$ in the three rivers Buriganga, Turag and Shitalakhya and the values ranged from $0.00-0.01,0.03-0.07$ and $0.00-0.05 \mathrm{mg} / \mathrm{l}$, respectively. Compared to these values, $\mathrm{Cu}$ concentrations at Tejgaon area showed increasing concentrations. Lethal $\mathrm{Cu}$ concentration for fish and aquatic invertebrates ranged from 0.02 - $3.0 \mathrm{mg} / \mathrm{l}$ (Lopez and Lee 1977). But for aquatic life and fish, 14 and 63\% water samples from this Tejgaon industrial area were above the " in excess of tolerable level" (Group 3, Table 4). In this respect high $\mathrm{Cu}$ concentration in the canal is also a threat to its fish community and aquatic invertebrates. Every year lots of dead fishes are found in the canal. Similar results were also reported by Mohuya et al. (2010) which were 0.101 6.135 and $0.002-0.018 \mathrm{mg} \mathrm{Cu} / \mathrm{l}$ in the Gulshan-Baridhara lake water during dry and wet season, respectively.

Toxic concentration level of $\mathrm{Cu}$ in plant is $15-20 \mathrm{mg} / \mathrm{kg}$ (Sauerbeck 1982). Mean concentration of $\mathrm{Cu}$ in plant samples were 23.88 and $33.16 \mathrm{mg} / \mathrm{kg}$ during wet and dry season, respectively (Fig. $4 \mathrm{C}$ and D). During 2nd sampling (dry season) $\mathrm{Cu}$ concentration in plant samples were higher than 1st sampling data (wet season). $\mathrm{Cu}$ concentration was above the toxic concentration limit in grass but low in other plant samples. $\mathrm{Cu}$ content was low in rice samples but above critical limit in other samples. During the 2nd sampling $\mathrm{Cu}$ concentrations in all plant samples, except a few, were above toxic concentration limit.

Table 3. Trace elements of some drinking water standards (DOE 1992, Zakarul et al. 2008).

\begin{tabular}{lllllll}
\hline Parameters & $\begin{array}{c}\text { WHO } \\
\text { standard }\end{array}$ & $\begin{array}{c}\text { EPA } \\
\text { standard }\end{array}$ & $\begin{array}{c}\text { Bangladesh } \\
\text { standard } \\
(\mu \mathrm{g} / \mathrm{l})\end{array}$ & $\begin{array}{c}\text { USPHS standard for } \\
\text { domestic water supply }\end{array}$ & $\begin{array}{c}\text { WHO } \\
\text { Standard } \\
(\mathrm{mg} / \mathrm{l})\end{array}$ & $\begin{array}{c}\text { DOE } \\
\text { Standard }\end{array}$ \\
\hline Lead & 50 & 15 & 50 & 50 & 0.01 & 0.05 \\
Cadmium & 10 & 5 & 5 & 10 & 0.003 & 0.005 \\
Iron (mg/l) & 0.3 & 0.3 & 0.3 & $<0.30$ & 0.3 & - \\
Zinc & - & 5000 & 5000 & 5000 & 3.0 & 5.0 \\
Copper & 1500 & 1300 & 1000 & 1000 & 2.0 & 1.0 \\
Chromium & 50 & 10 & 50 & 50 & 0.05 & 0.05 \\
Manganese & 50 & 50 & 100 & 100 & 0.05 & - \\
Nickel & - & 100 & 100 & 100 & 0.02 & 0.1 \\
\hline
\end{tabular}

Tejgaon industrial area soil was polluted with $\mathrm{Ni}, \mathrm{Pb}$ and $\mathrm{Cd}$ as reported by Chamon et al. (2005) (Ni-40.1, Pb-136 and Cd- $2.6 \mathrm{mg} / \mathrm{kg})$. In Dhanmondi lake, Pb concentrations varied from $0.151-0.210$ during the dry period and from $0.030-0.120$ during the wet period as reported by Ali et al. (1998). In summer, $\mathrm{Pb}$ concentrations in GulshanBaridhara lake ranged between 0.023 and $0.067 \mathrm{mg} /$ and $0.052-0.151 \mathrm{mg} / \mathrm{l}$ during monsoon as reported by Mohuya et al. (2010). 
The extent of contamination for water due to heavy metal deposition at Tejgaon industrial sites are presented in Table 4. The total heavy metal content of the water samples showed wide range of values from background to a level considered to reflect severe contamination especially lead. The extent of contamination (in \%) was identified by using information of background levels of total trace metal in water (DOE 1992) for Bangladesh.

In case of water samples, 82.76 and $42.11 \%(0-<0.05 \mathrm{mg} / \mathrm{l}) \mathrm{Cr}$ samples were found in the group of normal level, but in the group of in excess of tolerable level was 17.24 and $57.89 \%$ ( $\geq 0.05 \mathrm{mg} / \mathrm{l})$ during wet season and dry season, respectively (WHO 2004) (Table 4).

$89.47 \% \mathrm{Fe}(\geq 0.3 \mathrm{mg} / \mathrm{l}), 94.73 \% \mathrm{Mn}(\geq 0.05 \mathrm{mg} / \mathrm{l}), 100 \% \mathrm{~Pb}(>0.01 \mathrm{mg} / \mathrm{l}), 63 \% \mathrm{Cu}$ (>0.5 mg/l), $79 \% \mathrm{Cd}$ ( > $0.05 \mathrm{mg} / \mathrm{l}), 42.11 \% \mathrm{Ni}(>.01 \mathrm{mg} / \mathrm{l})$ and $57.89 \% \mathrm{Cr}(\geq 0.05$ $\mathrm{mg} / \mathrm{l}$ ) samples were found in the group of "in excess of tolerable level" during dry season, respectively (WHO 2004) (Table 4). During wet season the extent of contamination was lower compared to the dry season values for the above metals except $\mathrm{Pb}$. During both wet and dry seasons, $100 \% \mathrm{~Pb}$ (>0.01 mg/l) samples were found in the "group 3" (Table 4).

The extent of contamination due to heavy metal deposition in Tejgaon industrial sites is presented in Table 5. The total metal concentration of the plant samples showed wide range of values from background to a level considered to reflect severe contamination. The extent of contamination (in \%) was identified by using information of background levels (Sauerbeck 1982) of total trace metal concentration in plant samples.

Cadmium in plant samples were found in the group of in excess of tolerable level was $26 \%$ (>10 mg/kg) during rainy season. But in the dry season $79 \%$ (> $10 \mathrm{mg} / \mathrm{kg} \mathrm{Cd}$ ) plant samples were found in the group of in excess of tolerable level (Table 5). Plants take up $\mathrm{Pb}$ from solution without any hindrance. 33 and $59 \%$ (> $20 \mathrm{mg} / \mathrm{kg} \mathrm{Pb}$ ) of plant samples were found in the group of in excess of tolerable level during wet and dry season, respectively (Table 5). $\mathrm{Cu}$ concentration in plant samples were found in the group of in excess of tolerable level was 52 and $74 \%$ (> $20 \mathrm{mg} / \mathrm{kg}$ ) respectively, during wet and dry season (Table 5). Concentration of total $\mathrm{Ni}$ in plant samples, during 2nd sampling i.e. in dry season were found above the natural background level with few exceptions. Only $26 \%$ of $\mathrm{Ni}(<20 \mathrm{mg} / \mathrm{kg})$ plant samples were in the normal range and $74 \%(\geq 20-30$ $\mathrm{mg} / \mathrm{kg}$ ) samples were found in the group of in excess of tolerable level during wet season.

Chromium concentration in plant samples was found in the group of 'below toxic level' (< $1 \mathrm{mg} / \mathrm{kg}$ ) was 18.52 and $10.53 \%$ and in the group of 'within toxic level concentration' was 37.03 and $31.58 \%(1-2 \mathrm{mg} / \mathrm{kg}$ ) during wet season and dry season, respectively. $\mathrm{Cr}$ concentrations were found 'in excess of toxic level concentration' was 44.44 and $57.89 \%$ (> $2 \mathrm{mg} / \mathrm{kg}$ ) respectively, during wet season and dry season (Table 5). 


\section{DISCUSSION}

The $\mathrm{pH}$ dependence of the solution concentration of the trace element showed that the mobility and availability of the metals were high at strongly to extremely acid soil reaction (Chowdhury et al. 2007). The discharge of various types of waste materials from industries into the water bodies raise the concentration of metals. High content of $\mathrm{Cd}$ in the water samples might be due to discharge from the electroplating industries in the catchments of the canal and also from the surface drain pipe or septic tank pipe connected to the canal/study area.

High amount of $\mathrm{Cr}$ in the water samples might be due to discharge from the adjoining industries like tannery/leather, chemical manufacturing, textile etc. and also due to large amounts of particulate matter in the canal, which retained $\mathrm{Cr}$ as adsorbed ion. Acute toxicity of $\mathrm{Cr}$ to invertebrates is highly variable upon species (Brummer et al. 1983, Moore and Ramamoorthy 1984) and the concentration may create toxic effect on aquatic organisms. Pilling up of various types of garbage, household materials, cans, etc. near the study area increased $\mathrm{Cu}$ concentration of the studied samples (Mohuya et al. 2010).

During 1st sampling period, wet season had dilution of water due to influx of rain water and flood water from surrounding areas. Fresh water diluted and washed away much of the pollutants. But it was not enough to completely wash pollutants away. As water receded, the pollution load increased in the dry season than that the rainy season.

Expeditions to collect samples were extremely difficult due to the foul smell and unknown nature of gases emitting out of the water body. The soil (Chamon et al. 2009), water and air were unfit of any kind of human habitation. But a vast number of populations were living and working in the area disregarding the existing severe health hazards. Results show that the soil (DOE 1992, Ullah et al. 1999), water and plant (Alam 2006, Ullah et al. 1999) were of extremely low quality in the rainy season. Their quality deteriorated several fold in the dry season. In the rainy season the pollution was lowest because of heavy rainfall; most of the suspended materials, which were not complexed and precipitated with soil, organic matter and other compounds, were flushed out through the canal into the adjoining vast flood zone. As the rainy season receded the soils and water were enriched with the pollution load.

Plants take up heavy metals from solution without any hindrance. During the rainy season most plants were grass and water hyacinth with a few other plants. Most of the grasses and water hyacinth find their way into the food chain in the form of cattle feed. During the dry season rice, grass and many other types of 'rabi' crops, e.g., tomato, capsicum, cabbage, cauliflower, etc. were growing in the contaminated soils irrigated 
with these polluted water. $\mathrm{Pb}$ concentrations were very high and above critical level in all crops in both seasons.

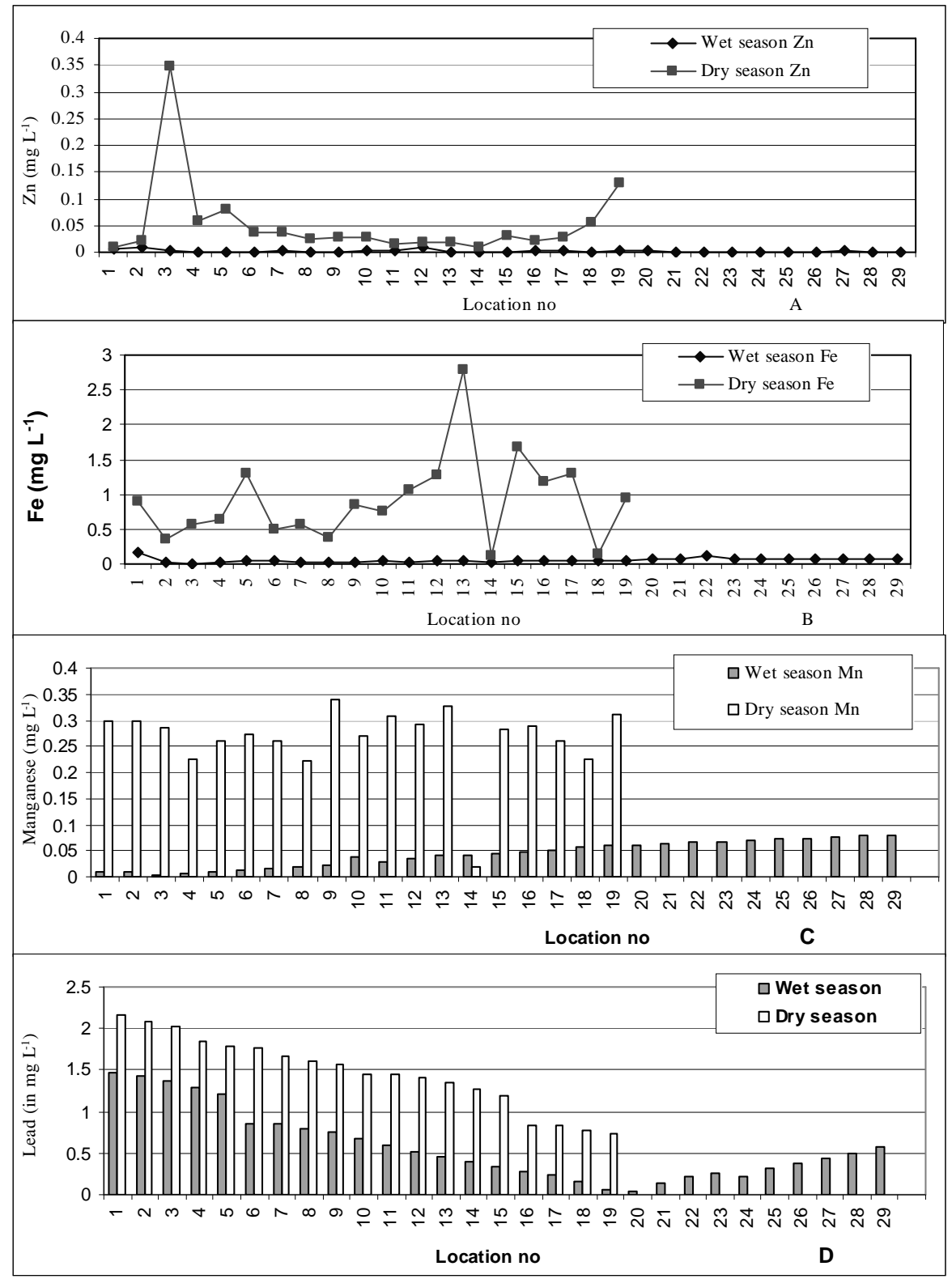

Fig. 2(A-D). Seasonal variation in heavy metal concentration in water samples at different locations around Tejgaon area: $\mathrm{Zn}(\mathrm{A}), \mathrm{Fe}(\mathrm{B}), \mathrm{Mn}(\mathrm{C}), \mathrm{Pb}(\mathrm{D})$. 


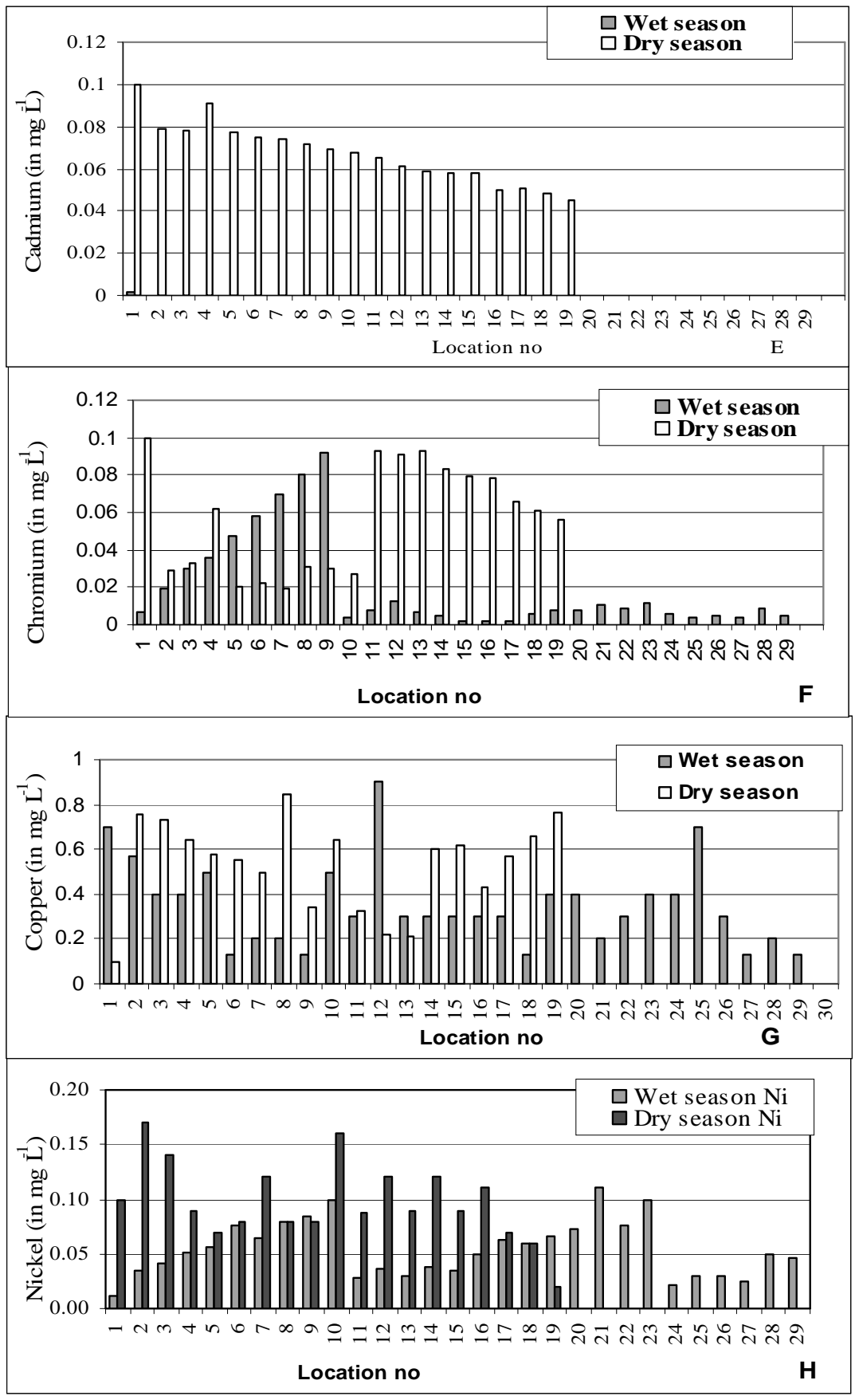

Fig. 2 (E-H). Seasonal variation in heavy metal concentration in water samples at different locations around Tejgaon area: $\mathrm{Cd}(\mathrm{E}), \mathrm{Cr}(\mathrm{F}), \mathrm{Cu}(\mathrm{G}), \mathrm{Ni}(\mathrm{H})$. 


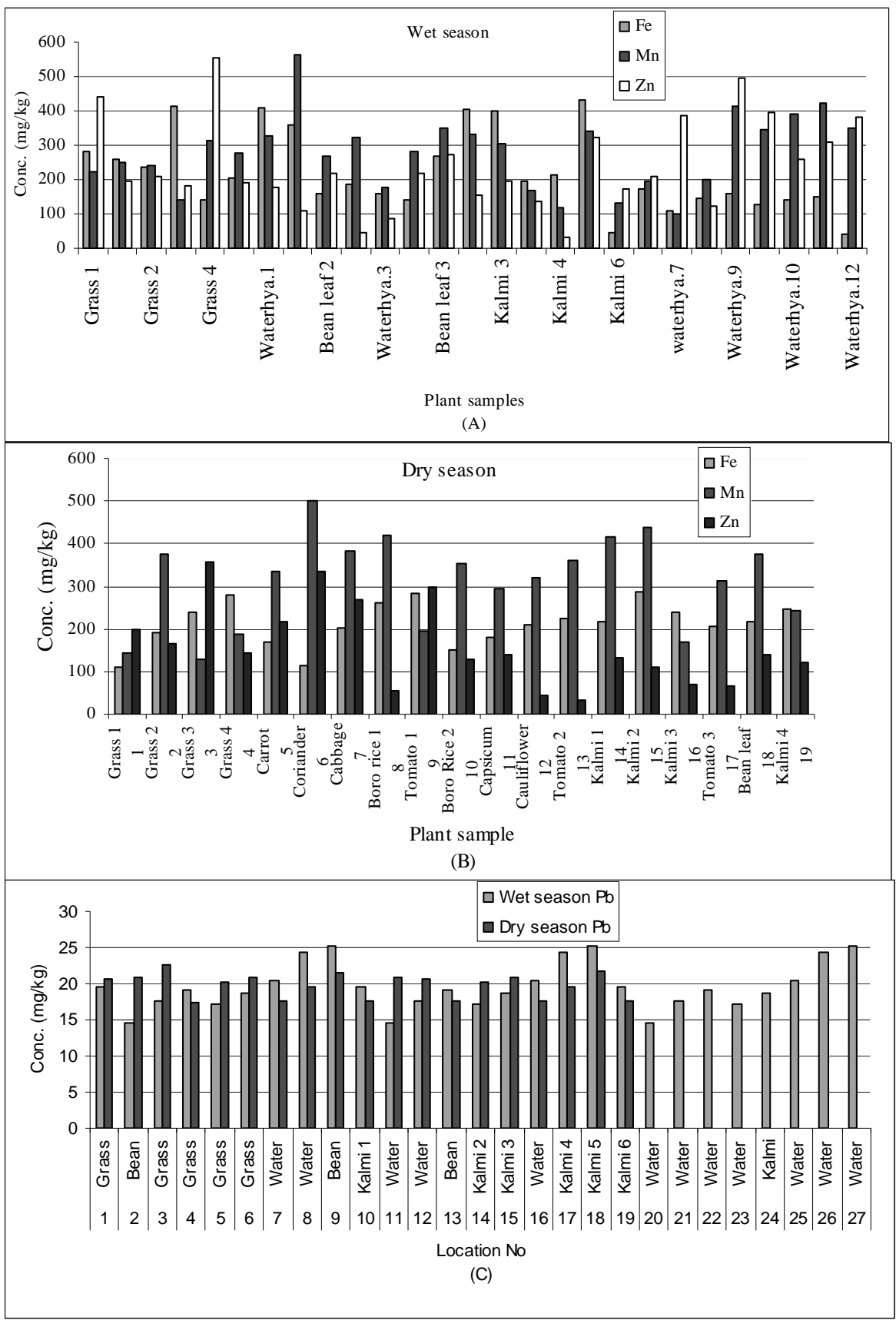

Fig. 3 (A-C). Seasonal variation in heavy metal concentration in plant samples at different locations around Tejgaon area: $\mathrm{Fe}, \mathrm{Mn} \& \mathrm{Zn}(\mathrm{A})$ and $(\mathrm{B}), \mathrm{Pb}(\mathrm{C})$. 


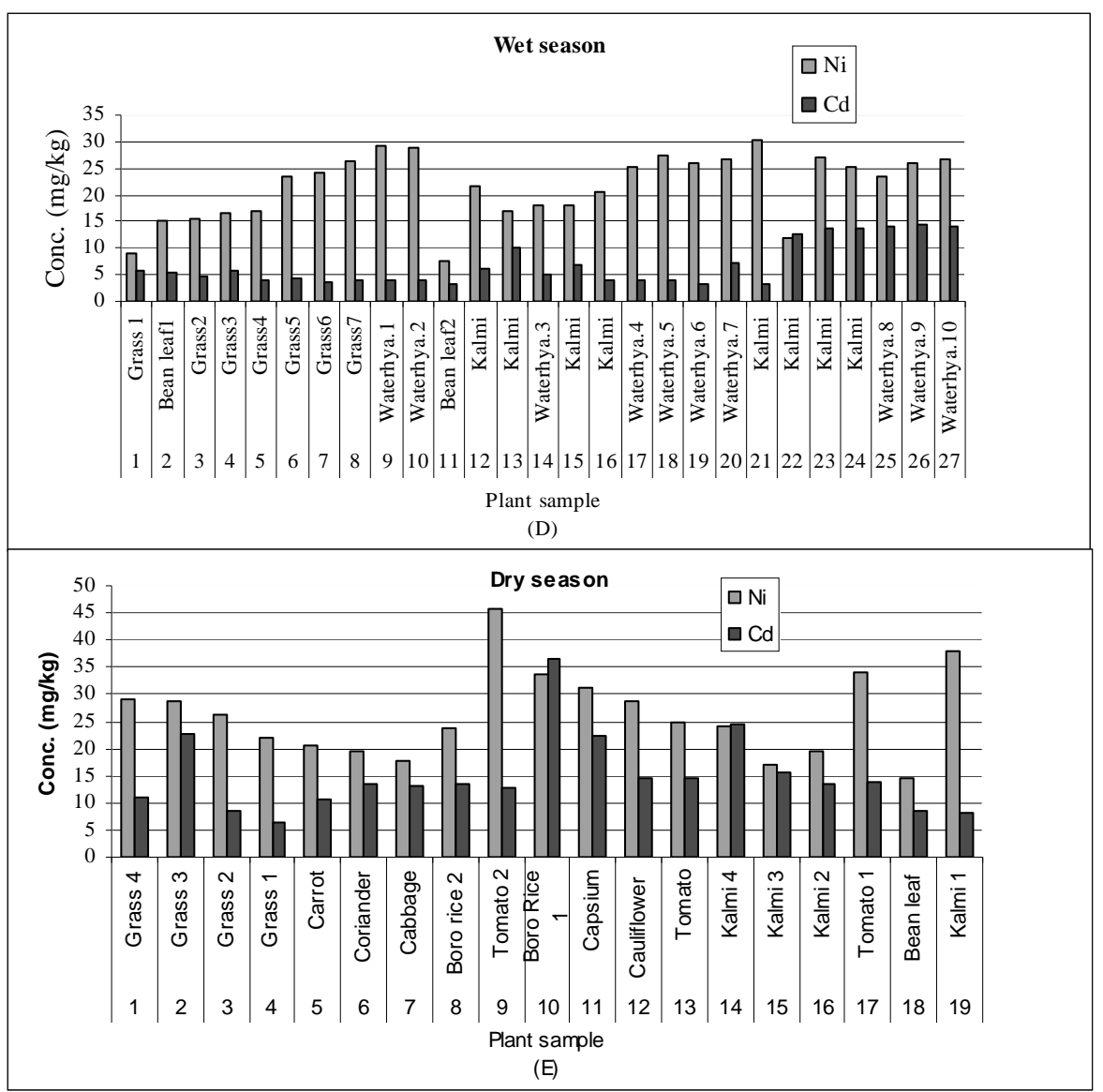

Fig. 3 (D-E). Seasonal variation in heavy metal concentration in plant samples at different locations around Tejgaon area: $\mathrm{Ni} \& \mathrm{Cd}(\mathrm{D})$ and (E).

One of the most alarming facts is that some sampling points under investigation were apparently far from the pollution source. Bumper crops were being produced in the vicinity of Balu river. Consumers have no idea that locally produced crops with attractive appearances have high pollution content of heavy metals like $\mathrm{Pb}, \mathrm{Cd}, \mathrm{Cr}$ and $\mathrm{Ni}$.

From the results of the experiment it can be clearly stated that the concentrations of studied pollutants were higher during the dry season particularly in the month of January, when the rainfall was comparatively low. But during the monsoon the values were in general low and fall within various standard levels. This adjustment might have occurred because of rainfall and dilution. Only in the case of lead, concentration level was high during the wet season. It might be due to the high percentage of lead in Dhaka's air in recent time which mixed up with rain water during monsoon and finally reached to the water bodies through precipitation. 


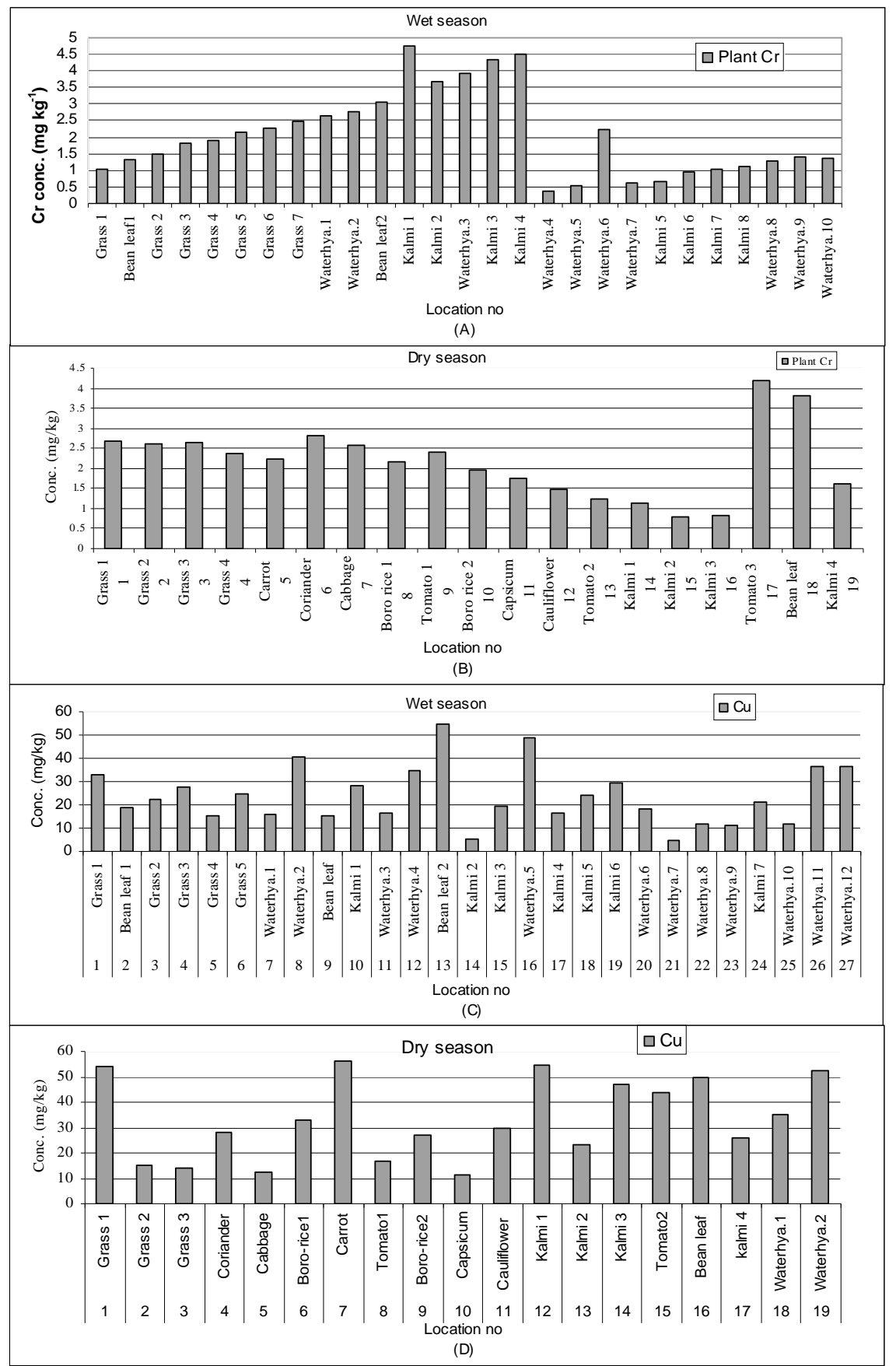

Fig. 4. Seasonal variation in heavy metal concentration in plant samples at different locations around Tejgaon area: $\mathrm{Cr}(\mathrm{A}),(\mathrm{B})$ and $\mathrm{Cu}(\mathrm{C})$ and (D). 
Discharge of $\mathrm{Pb}$ from the adjoining battery industries, and pesticides application to the farmer's field might be another reason. Lead concentrations exceeded the standards of drinking water at all locations. When the fishing-, industrial- and irrigation water standards were taken into concentration, $\mathrm{Pb}$ concentration exceeded the standard level $(0.01 \mathrm{mg} /)$.

The addition of pollutants leads to the shift in flora and fauna due to homeostatic factors operating in the aquatic systems. The diversity of organisms decreases due to presence of only a few tolerant forms in the polluted conditions.

Table 4. Extent of contamination according to total trace metal concentration in water $(\mathrm{mg} / \mathrm{l})$ during wet and dry seasons' sampling. Percentage of sampling locations in parentheses.

\begin{tabular}{|c|c|c|c|}
\hline Metals & Group 1 & Group 2 & Group 3 \\
\hline $\mathrm{Pb}$ (wet season) $(\mathrm{n}=29)$ & $0.00-<0.01(0)$ & $0.01-\leq 0.01(0)$ & $>0.01(100)$ \\
\hline $\mathrm{Pb}($ dry $”)(\mathrm{n}=19)$ & $0.00-<0.01(0)$ & $0.01-\leq 0.01(0)$ & $>0.01(100)$ \\
\hline $\mathrm{Cu}($ wet $")(\mathrm{n}=29)$ & $0.00-<0.5(79)$ & $0.5(7)$ & $>0.5(14)$ \\
\hline $\mathrm{Cu}($ dry $”)(\mathrm{n}=19)$ & $0.00-<0.5(32)$ & $0.5(5)$ & $>0.5(63)$ \\
\hline $\mathrm{Ni}($ wet $")(\mathrm{n}=29)$ & $0.00-<0.01(0)$ & $>0.01 \leq 0.1(100)$ & $>0.1(0)$ \\
\hline Ni (Dry " $)(n=19)$ & $0.00-<0.01(0)$ & $>0.01 \leq 0.1$ & $>0.1(42.11)$ \\
\hline Cd (wet $")(n=29)$ & $0.00-<0.05(100)$ & $0.05(0)$ & $>0.05(0)$ \\
\hline Cd (dry " $)(n=19)$ & $0.00-<0.05(0)$ & $0.05(21)$ & $>0.05(79)$ \\
\hline & Below tolerable level & \multicolumn{2}{|c|}{ In excess of tolerable level } \\
\hline Cr (wet season) $(n=29)$ & $0.00-<0.05(82.76)$ & \multicolumn{2}{|l|}{$\geq 0.05(17.24)$} \\
\hline Cr (dry ”) $(\mathrm{n}=19)$ & $0.00-<0.05(42.11)$ & \multicolumn{2}{|l|}{$\geq 0.05(57.89)$} \\
\hline $\mathrm{Fe}($ wet $”)(\mathrm{n}=29)$ & $0.00-<0.3(100)$ & \multicolumn{2}{|l|}{$\geq 0.3(0)$} \\
\hline Fe (dry $")(n=19)$ & $0.00-<0.3(10.5)$ & \multicolumn{2}{|l|}{$\geq 0.3(89.47)$} \\
\hline Mn (wet ”) $(n=29)$ & $0.00-<0.05(48.28)$ & \multicolumn{2}{|l|}{$\geq 0.05(51.72)$} \\
\hline $\operatorname{Mn}($ dry $\quad ")(n=19)$ & $0.00-<0.05(5.26)$ & \multicolumn{2}{|l|}{$\geq 0.05(94.73)$} \\
\hline Zn (wet ") $(\mathrm{n}=29)$ & $0-5.0(100)$ & \multicolumn{2}{|l|}{$\geq 5.0(0)$} \\
\hline Zn (dry " $)(n=19)$ & $0.00-5(100)$ & \multicolumn{2}{|l|}{$\geq 5.0(0)$} \\
\hline
\end{tabular}

Group 1 = Background level, group 2 = Maximum tolerable level and group 3 = In excess of tolerable level.

Background concentration for $\mathrm{Pb}=0.00-<0.01 \mathrm{mg} / \mathrm{l} \mathrm{ppm}$ of drinking water of Bangladesh (WHO 2004). Tolerable total concentrations is $\leq 0.01 \mathrm{ppm}$ for $\mathrm{Pb}$ (WHO 2004).

Background concentration for $\mathrm{Cu}=0.00-<0.5 \mathrm{mg} \mathrm{L}^{-1} \mathrm{ppm}$ of inland surface water of Bangladesh (for fish and aquatic life) (DOE 1992). Tolerable total concentrations is $\leq 0.5 \mathrm{ppm}$ for $\mathrm{Cu}$ for fish and aquatic life. Background concentration for $\mathrm{Ni}=0.00-<0.1 \mathrm{mg} / \mathrm{l} \mathrm{ppm}$ of drinking water of Bangladesh (DOE 1992). Background concentration for $\mathrm{Cd}=0.00-<0.05 \mathrm{mg} / \mathrm{l}$ of inland surface water of Bangladesh (DOE 1992). Tolerable total concentration upto $0.05 \mathrm{mg} / \mathrm{l}$ for Cd (DOE 1992).

Tolerable total concentrations is $0.05,0.3,0.05$ and $5.0 \mathrm{mg} / \mathrm{l}$ for $\mathrm{Cr}, \mathrm{Fe}, \mathrm{Mn}$ and $\mathrm{Zn}$. respectively (WHO 2004). 
Table 5. Extent of contamination in plants $(\mathrm{mg} / \mathrm{kg})$ during wet and dry seasons (Percentage of sampling locations in parentheses).

\begin{tabular}{|c|c|c|c|}
\hline Trace elements & Group 1 & Group 2 & Group 3 \\
\hline Cd (wet season) $(n=27)$ & $3-<5.0(48)$ & $5-10(26)$ & $>10(26)$ \\
\hline Cd(dry ") $(n=19)$ & $3-<5.0(0)$ & $5-10(21)$ & $>10(79)$ \\
\hline $\mathrm{Pb}($ wet $\quad ")(\mathrm{n}=27)$ & $0-<10(0)$ & $>10-\leq 20(67)$ & $>20(33)$ \\
\hline $\mathrm{Pb}($ dry $\quad ")(\mathrm{n}=19)$ & $0-<10(0)$ & $>10-\leq 20(41)$ & $>20(59)$ \\
\hline $\mathrm{Cu}($ wet $\quad ”)(\mathrm{n}=27)$ & $5-<15(18.5)$ & $15-20(26)$ & $>20(52)$ \\
\hline $\mathrm{Cu}($ dry $\quad ")(\mathrm{n}=19)$ & $5-<15(16)$ & $15-20(11)$ & $>20(74)$ \\
\hline Ni (wet $\quad ")(n=27)$ & $<20(37)$ & $\leq 20(0)$ & $>20-30(63)$ \\
\hline \multirow[t]{3}{*}{ Ni (Dry } & $<20(26)$ & $\leq 20(0)$ & $>20-30(74)$ \\
\hline & \multicolumn{2}{|c|}{ Below tolerable level } & In excess of tolerable level \\
\hline & Below toxic level & Within toxic conc. level & In excess of toxic conc. level \\
\hline $\mathrm{Cr}$ (wet season) $(\mathrm{n}=27)$ & $<1(18.52)$ & $1-2(37.03)$ & $>2(44.44)$ \\
\hline Cr (dry $\quad ")(n=19)$ & $<1(10.53)$ & $1-2(31.58)$ & $>2(57.89)$ \\
\hline $\mathrm{Fe}($ wet $\quad ")(\mathrm{n}=27)$ & $0-<50(7.41)$ & $50-250(59.26)$ & $>250(33.33)$ \\
\hline $\mathrm{Fe}(\operatorname{dry} \quad ")(\mathrm{n}=19)$ & $0-<50(0)$ & $50-250(78.95)$ & $>250(21.05)$ \\
\hline $\mathrm{Zn}($ wet $\quad ")(\mathrm{n}=27)$ & $0-<150(22.22)$ & $150-200(25.93)$ & $>200(51.85)$ \\
\hline \multirow[t]{2}{*}{ Zn (dry " ) (r } & $0-<150(63.16)$ & $150-200(10.53)$ & $>200(26.32)$ \\
\hline & Below normal range & Within normal range & Above normal range \\
\hline Mn (wet season) $(n=27)$ & - & $20-500(100)$ & - \\
\hline $\operatorname{Mn}($ dry $\quad ")(n=19)$ & - & $20-500(100)$ & - \\
\hline
\end{tabular}

Group 1 = Background level, group 2 = Maximum tolerable level and group 3 = In excess of tolerable level.

Background concentration for $\mathrm{Cd}=3-<5.0$ (Sauerbeck 1982, Melsted 1973) $\mathrm{mg} / \mathrm{kg}$. Tolerable total concentrations are $5-10 \mathrm{mg} / \mathrm{kg}$ for Cd (Sauerbeck 1982). Background concentration for $\mathrm{Pb}=0-<10$ $\mathrm{mg} / \mathrm{kg}$ (Sauerbeck 1982). Toxic concentrations is $10-20 \mathrm{mg} / \mathrm{kg}$ for $\mathrm{Pb}$ (Sauerbeck 1982). Background concentration for $\mathrm{Cu}=5-<15 \mathrm{mg} / \mathrm{kg}$ (Tisdale and Nelson 1985). Tolerable total concentrations is $15-20$ $\mathrm{ppm}$ for $\mathrm{Cu}$ (Sauerbeck 1982). Background concentration for $\mathrm{Ni}=<20 \mathrm{mg} / \mathrm{kg}$ (Sauerbeck 1982). Tolerable total concentrations are $\leq 20 \mathrm{ppm} \mathrm{Ni}$ and in excess of tolerable total concentrations is $20-30$ $\mathrm{ppm}$ for $\mathrm{Ni}$ (Sauerbeck 1982). Toxic level concentrations is $1-2 \mathrm{mg} / \mathrm{kg}$ for $\mathrm{Cr}$ (Sauerbeck 1982). Sufficiency range for $\mathrm{Fe}$ is $50-250 \mathrm{mg} / \mathrm{kg}$ (Tisdale and Nelson 1985). Normal range for $\mathrm{Mn}$ is $20-500$ and for $\mathrm{Zn}$ is $25-150 \mathrm{mg} / \mathrm{kg}$ (Tisdale and Nelson 1985). Toxic conc. level for $\mathrm{Zn}$ is $150-200 \mathrm{mg} / \mathrm{kg}$ (Sauerbeck 1982).

Table 6. Normal, sufficiency and toxic conc. level for heavy metals in plants and soil.

\begin{tabular}{|c|c|c|c|c|c|c|c|}
\hline \multirow{2}{*}{$\begin{array}{l}\text { Plant (in general) (Tisdale and } \\
\text { Nelson } 1985 \text { ) }\end{array}$} & \multicolumn{2}{|c|}{$\mathrm{Fe}$} & \multicolumn{2}{|c|}{$\mathrm{Mn}$} & \multicolumn{3}{|c|}{$\mathrm{Zn}$} \\
\hline & & & & $\mathrm{mg} / \mathrm{kg}$ & & & \\
\hline Sufficiency range & $50-250$ & & - & & - & & \\
\hline Normal range & - & & $20-500$ & & $25-150$ & & \\
\hline Toxicity & - & & - & & $>400$ & & \\
\hline $\begin{array}{l}\text { Plant (in general) (Sauerbeck } \\
\text { 1982) }\end{array}$ & $\mathrm{Cd}$ & $\mathrm{Cr}$ & $\mathrm{Cu}$ & $\mathrm{Ni}$ & $\mathrm{Pb}$ & Co & \\
\hline Toxic conc. level (mg/kg) & $5-10$ & $1-2$ & $15-20$ & $20-30$ & $10-20$ & $10-20$ & \\
\hline $\begin{array}{l}\text { Tolerable total conc. in } \\
\text { soil (Kloke 1980) }(\mathrm{mg} / \mathrm{kg})\end{array}$ & 3.0 & 100 & 100 & 50 & 100 & $\begin{array}{l}\mathrm{Zn} \\
300\end{array}$ & $\begin{array}{l}\mathrm{Mn} \\
1000\end{array}$ \\
\hline
\end{tabular}




\section{CONCLUSION}

Within this research program, the study was carried out to evaluate the contamination and seasonal variation of toxic metals in the water and plant samples at different locations of Tejgaon industrial area. The specific aims of the research are to the determination of heavy metal toxicity indicators in different kinds of plants in different locations.

The study area consisted of two distinct areas. The industries at Tejgaon are discharging their wastes and effluents in the natural systems in most cases without any treatment and thereby cause environmental pollution especially due to heavy metals and organic toxins. The hazardous wastes and effluents are generally discharged in low-lying areas, along the road sides or in the vicinity of the industrial installations. Besides, fertilizers, pesticides and the contaminated water (for irrigation purposes) are being randomly used in agricultural lands by the farmers.

The investigations under this project showed that industrial effluents and wastes lead to significant pollution of water around Dhaka city. The important heavy metals discharged from industries in the study area are cadmium, lead, chromium, and in few cases iron and manganese. Trace metals as shown in the wet and dry season sampling considered above the maximum tolerable limit value (CPCB 1995). 100, 63, 42, 79, 58 and 95\% water samples were in the group of in excess of tolerable level during dry season for $\mathrm{Pb}, \mathrm{Cu}, \mathrm{Ni}$, $\mathrm{Cd}, \mathrm{Cr}$ and $\mathrm{Mn}$. Kalmi, water hyacinth, grass (in wet season) and Boro rice, cabbage (in dry season) accumulated the maximum concentration of $\mathrm{Fe}$ and $\mathrm{Mn}$.

In the rainy season the pollution was lower because of heavy rainfall, were flushed out through the canal into the adjoining vast flood zone. As the rainy season receded the soils (Chamon et al. 2009, Ullah et al. 1999) and water were enriched with the pollution load.

\section{ACKNOWLEDGEMENTS}

Authors wish to thank the Secretary, Ministry of Science and Information Technology, Government of the People's Republic of Bangladesh for his kind approval of the project "Speciation of Heavy Metals in Soils, Plants and Water of Bangladesh".

The authors wish to thank the Vice Chancellor, Dhaka University, Dhaka and the Chairman, Department of Soil, Water and Environment, DU for their active support in pursuing the research programme. They also thank to the Senior Scientist and Director of the Centre for Advanced Research in Physical, Chemical, Biological and Pharmaceutical Sciences, DU for their help in analyzing heavy metals in atomic absorption spectrophotometer. 


\section{REFERENCES}

Adriano, D.C. (Ed). 1986. Elements in the Terrestrial Environment. Springer Verlag: New York, $145-60$.

Ahmed Aksoy, Dilek Demirzen and Fatih Duman. 2005. Bioaccumulation, detection and analyses of heavy metal pollution in sultan marsh and environment. Water, Air and Soil Pollution 164: 241.

Alam, M.N. 2006. Risk assessment and evaluation quality of Sitalakhya river due to industrial effluents at year 2004 to 2005. MS Thesis, Dept. of Soil, Water and Environment, Dhaka University, Dhaka. 105-110.

Ali, A., A.N.M. Ahsanuzzaman, A.B.M. Badruzzaman, and M.M. Rahman, 1998. Lead pollution of Dhanmondi lake in Dhaka. J. Water SRT. Aquq. 47: 289-296.

Baker, A.J.M. 1991. Accumulation and Excluders strategies in the response of plants to heavy metals. J. Plant Nutr. 3: 643-654.

Bashar, M.A., S.M. Ullah, H.G. Waibacher and B. Ullah. 2007. Heavy metals in the water of some Chittagong Region River Systems. J. Asiat. Soc. Bangladesh. Sci. 33(1): 57-68.

Brummer, G., K.G. Tiller, U. Herms, and P.M. Clayton. 1983. Adsorption-desorption and/or precipitation-dissolution processes of zinc in soils. Geoderma. 31: 337-354.

Cataldo, D.A. and R.E. Wildung. 1978. Soil and plant factors influencing the accumulation of heavy metals by plants. Environ. Health Pers. 27: 149-159.

Chamon A.S., M.N. Mondol, B. Faiz, M.H. Rahman and S.F. Elahi. 2008. Speciation analysis of Ni in the soils of Tejgaon industrial area of Bangladesh. Bangladesh J. Sci. Ind. Res. 44(1): 87108.

Chamon, A.S., W.E.H. Blum, M.H. Gerzabek, S.M. Ullah, M. Rahman and M.N. Mondol. 2005. Heavy metal uptake into crops on polluted soils of Bangladesh. I. Influence of crop and crop varieties. J. Comm. Soil Sci. Plant Analysis. 36: 889-906.

Chowdhuri, A.M.S., M.A. Rahman, M.M. Rahman, A.S.M. Mohiuddin and M.B. Zaman. 2007. Nature and extent of industrial pollution in river water around Dhaka city. Bangladesh J. Environ. Sci. 13(1): 45-49.

CPCB. 1995. Central Pollution Control Board. In : Methods of Environmental Analysis of Soil, Plant and Water. Gupta (ed). New Delhi. pp. 22.

DOE (Department of Environment). 1992. Environmental Quality Standards for Bangladesh. Report.

Elahi, S.F., A.S. Chamon, B. Faiz, M.H. Rahman and M.N. Mondol. 2008. Physico-chemical properties of soils, plants and water of Tejgaon soil. Bangladesh J. Environ. Sci. 14(1): 153-160.

Hach. 1997. Hach Water Analysis Handbook. 3rd ed. Hach Company, Loveland, Colorado, USA. pp. 1246-1253.

Kabata-Pendias, A., Piotrowska, A.M., Dudka, S. 1993. Trace metals in legumes and monofyledors and their suitability to the assessment of soil contamination. In : Plants as Biomonotors. B. Markert, Ed.;Weinhaum: Berlin,Germany. pp. 485-494.

Loneragan, J.P. 1975. The availability and absorption of trace elements in soil-plant systems and their relation to movement and concentrations of trace elements in plants. In D.J.D. Nicholas and A.R. Rogan (Eds), Trace elements in soil-plant systems. Academic Press, New York: USA, pp. 109-134.

Lopez, J.N. and G.F. Lee. 1997. Evvironmental chemistry of copper in Torch lake, Michigan. J. Water, Air and Soil Pollution. 8: 373-385. 
Mohuya, F.A., R. H. Bhuiyan and S. Haque. 2010. Heavy metal contamination in GulshanBharidhara lake. Dhaka. Dhaka Univ. J. Biol. Sci. 19(1): 53-61.

Moore, J.W. and S. Ramamoorthy. 1984. Heavy metals in natural waters: Applied monitoring and impact assessment. Springer-Verlag, New York, New York-Berlin-Heidelberg-Tokyo. 28: 268.

Rahman, K. 1992. Industrial pollution and control for sustainable development. Training manual on environmental management in Bangladesh. Department of Environment; Dhaka, Bangladesh. pp. 184-206.

Sauerbeck, D. 1982. Welche Schwermetallgehalte in Pflanzen dürfen nicht überschritten werden, um Wachstumsbeeinträchtigungen zu vermeiden? Landw. Forsch. Sonderheft, Kongressband. 39: $108-129$.

Sparks, D.L., A.L. Page., P.A. Helmke, R.H. Loepert, P.N. Soltanpour, M.A. Tabatabai, C.T. Johnston and M.E. Sumner. 2001. Methods of soil analysis. Volumes 1, 2 \& 3. SSSA Book Series 5. 3rd Printing. Pub. by Soil Science Society of America, Segoe Street, Madison, WI. USA.

Tisdale and Nelson. 1985. Fertility and Fertilizer. Macmillan Publishing Company. 866 Third Avenue. New York. pp. 81-85.

Ullah, S.M., M.H. Gerzabek, M.N. Mondol, M.M. Rashid and M. Islam. 1999. Heavy metal pollution of soils and water and their transfer into plants in Bangladesh. In : Proc. of extended Abstracts. 5th International Conference on the Biogeochemistry of Trace Elements (Wenzel. W.W., D.C.Adriano, B.Alloway, H.E. Doner, C. Keller, N.W. Lepp, M. Mench, R. Naidu and G.M. Pierzynski. (Eds) Vienna, Austria. 1, 260-261.

WHO. 2004. Guidelines for Drinking-Water Quality. World Health Organization. Geneva. pp. 296-460.

Zakarul Mohammad Islam, M. A. Azim and R. Islam. 2008. Seasonal variation of heavy metals in water samples from the Sitalakhya river. J. Bangladesh Academy Sci. 32(1): 13-22.

(Received revised manuscript on 28 February, 2011) 